\title{
Metode Experiental Learning dalam Pembelajaran Akidah Akhlak di SMA An Nuriyyah Bumiayu
}

\author{
Debi Musdalifah* \\ SMA An-Nuriyah Bumiayu, Brebes
}

\begin{abstract}
Keywords:
Akidah Akhlak, Experiental

Learning, Response
\end{abstract}

Kata Kunci:

Akidah Akhlak, Experiental

Learning, Respon

*Correspondence Address: debimusdalifah800@gmail.com

\begin{abstract}
The teaching and learning of Aqidah Akhlak is part of islamic learning process. This particular learning is much in touch with the nature and the human spirit, that is why the learning Aqidah Akhlak is recognized as the type of 'teaching about thinking'. This type of learning is directed at efforts to help students to be aware of their thought processes. The Learning methods that are appropriate for this type of learning are participatory methods, such as discussions, simulations, projects, and experiential learning. The purpose of this study is to describe the planning and implementation of experiential learning methods in the learning process of Aqidah Akhlak in An Nuriyyah Bumiayu High School and students' responses to Aqidah Akhlak subjects with experiential learning methods. This research is a descriptive study, a research that seeks to describe a specific symptom or event with qualitative data. The data analysis used in this study is the analysis of interactive model data by using the process of reduction, display and verification. The experiential learning method in the learning process of Aqidah Akhlak in An Nuriyyah Bumiayu High School is shown to give some improvement for students' responses to Aqidah Akhlak learning process, which is shown with enthusiasm of students in participating in the learning process. In addition, this method is able to bring up excitement so that in a pleasant atmosphere, moral subjects can strengthen students' faith.
\end{abstract}

Abstrak: Pembelajaran Akidah Akhlak merupakan bagian dari pembelajaran Pendidikan Agama Islam. Pembelajaran ini banyak bersentuhan dengan fitrah dan jiwa manusia. Oleh karena itu, pembelajaran Akidah Akhlak termasuk dalam jenis pembelajaran teaching about thinking. Jenis pembelajaran ini diarahkan pada upaya untuk membantu peserta didik agar sadar terhadap proses berfikirnya. Metode pembelajaran yang sesuai untuk jenis pembelajaran seperti ini adalah metode partisipatif, seperti diskusi, simulasi, proyek, dan experiental learning. Tujuan penelitian ini adalah mendeskripsikan perencanaan dan pelaksanaan metode experiental learning dalam pembelajaran Akidah Akhlak di SMA An Nuriyyah Bumiayu dan respon peserta didik terhadap mata pelajaran Akidah Akhlak dengan metode experiental learning. Penelitian ini merupakan penelitian deskriptif, yaitu penelitian yang berusaha mendeskripsikan suatu gejala, peristiwa, atau kejadian tertentu dengan data yang bersifat kualiatif. Adapun analisis data yang digunakan dalam penelitian ini adalah analisis data model interaktif, yaitu melalui proses reduksi, penyajian dan verifikasi. Metode experiental learning dalam pembelajaran Akidah Akhlak di SMA An Nuriyyah Bumiayu ini mampu meningkatkan respon peserta didik terhadap pembelajaran Akidah Akhlak, di antaranya ditampakkan dengan dengan semangat dan antusiasme peserta 
didik dalam mengikuti pembelajaran. Selain itu, metode ini mampu memunculkan kegembiraan sehingga dalam suasana menyenangkan, mata pelajaran Akidah Akhlak dapat menjadi penyejuk dan penguat iman peserta didik.

\section{Pendahuluan}

Tujuan pendidikan Islam pada dasarnya adalah tujuan hidup manusia itu sendiri, sebab tugas pendidikan adalah memelihara kehidupan manusia. Berdasarkan hal itulah maka Langgulung menyimpulkan bahwa tujuan pendidikan Islam adalah membentuk pribadi khalifah bagi peserta didik yang memiliki fitrah, ruh, kemauan, dan akal, sehingga pendidikan bertugas untuk mengembangkan keempat aspek tersebut agar ia eksis dalam kekhalifahannya sebagai wujud pengabdian terhadap Tuhan. ${ }^{1}$

Pendidikan Agama Islam (PAI) merupakan salah satu bagian dari pendidikan Islam. Hal ini dapat dilihat dari penggunaan istilah "pendidikan Islam" yang dapat dipahami dalam beberapa perspektif. Pertama, pendidikan menurut Islam, yaitu pendidikan yang dipahami dan dikembangkan serta disusun dari ajaran dan nilai-nilai fundamental yang terkandung dalam alQuran dan Hadits. Kedua, pendidikan keIslaman atau pendidikan agama Islam, yaitu upaya mendidik agama Islam atau ajaran Islam dan nilai-nilainya agar menjadi way of life (pandangan dan sikap hidup seseorang). Ketiga, pendidikan dalam Islam yang berarti proses tumbuh kembangnya pendidikan Islam dan umatnya. ${ }^{2}$

Berdasarkan rumusan tujuan pendidikan Islam dan Pendidikan Agama Islam yang dikemukakan oleh para ahli pendidikan Islam tersebut, dapat

1 Hassan, Langgulung, Manusia dan Pendidikan; Suatu Analisa Psikologi dan Pendidikan, (Jakarta: Pustaka Al Husna, 1986), 56

2 Muhaimin,Nuansa Baru Pendidikan Islam, Mengurai Benang Kusut Pendidikan Islam, (Jakarta: PT Raja Grafindo Persada, 2006), 4 disimpulkan bahwa tujuan utama dalam Pendidikan Agama Islam bukan hanya meliputi knowing (mengetahui tentang ajaran atau nilai-nilai agama) ataupun doing (bisa mempraktikkan) apa yang diketahui setelah diajarkan di sekolah, tetapi justru lebih mengutamakan beingnya (beragama) atau menjalani hidup atas dasar ajaran dan nilai agama. Karena itu bidang Pendidikan Agama Islam harus lebih diorientasikan pada tataran moral action, yakni agar peserta didik tidak hanya berhenti pada tataran competence tetapi sampai memiliki kemauan (will) dan kebiasaan (habit) dalam mewujudkan ajaran dan nilai-nilai agama tersebut dalam kehidupan sehari-hari. ${ }^{3}$

Muhaimin, menjelaskan bahwa pelajaran Akidah Akhlak tidak sekadar terkonsentrasi pada persoalan teoretis yang bersifat kognitif semata, tetapi sekaligus juga mampu mengubah pengetahuan Akidah Akhlak yang bersifat kognitif menjadi makna dan nilai-nilai yang perlu diinternalisasikan dalam diri peserta didik lewat berbagai cara, media, dan forum. Selanjutnya "makna" dan "nilai" yang terhayati tersebut dapat menjadi sumber motivasi bagi peserta didik untuk bergerak, berbuat, berperilaku secara konkrit agamis dalam kehidupan praksis sehari-hari. ${ }^{4}$

Kenyataan di lapangan menunjukkan bahwa proses pembelajaran Akidah Akhlak lebih banyak menekankan pada akumulasi pengetahuan materi pelajaran semata

3 Muhaimin, Nuansa Baru Pendidikan Islam, Mengurai Benang Kusut Pendidikan Islam,(Jakarta: PT Raja.Grafindo Persada, 2006), 147

4Muhaimin, Wacana Pengembangan Pendidikan Islam, (Surabaya: Pusat Studi Agama, Politik, dan Masyarakat PSAPM, 2003), 313 
dan kurang memperhatikan kemampuan peserta didik untuk memperoleh pengetahuannya lewat proses pembelajaran. Sehingga transformasi nilai-nilai Akidah Akhlak hingga dapat menjadi being bagi peserta didik menjadi tidak maksimal. pembelajaran dalam aspek Akidah Akhlak yang telah ada, hanya cenderung mengarah pada paham fatalistik dan truth claim. ${ }^{5}$

Muhaimin mengatakan bahwa pendidikan agama diajarkan sebagai kegiatan rutin agama dan kurang ditekankan sebagai proses pembentukan kepribadian. Sebagai dampak yang menyertai situasi tersebut, maka Guru pendidikan agama Islam kurang berupaya menggali berbagai metode yang mungkin bisa dipakai dalam pendidikan agama sehingga pelaksanaan pembelajaran cenderung monoton. ${ }^{6}$

Mengenai pentingnya pemilihan metode dalam pembelajaran, Budiningsih menjelaskan bahwa upaya untuk memperbaiki kualitas pembelajaran terletak pada strategi pembelajaran dalam bentuk variabel metode pembelajaran. ${ }^{7}$ Menurut Uno, variabel metode pembelajaran diklasifikasikan menjadi tiga, yaitu; (1) strategi pengorganisasian pembelajaran; (2) strategi penyampaian pembelajaran; (3) strategi pengelolaan pembelajaran. Sedangkan variabel yang berpengaruh terhadap penggunaan metode pembelajaran adalah variabel kondisi pembelajaran. Variabel ini dikelompokkan menjadi tiga, yaitu; (1) tujuan dan karakteristik materi/bidang studi; (2) kendala dan karakteristik

${ }^{5}$ Muhaimin, Nuansa Baru Pendidikan Islam, Mengurai Benang Kusut Pendidikan Islam, (Jakarta: PT Raja. Grafindo Persada, 2006), 171

6 Muhaimindan Sutiah, Paradigma Pendidikan Islam, (Bandung: Remaja Rosda Karya, cet. 2, 2002), 88

${ }^{7}$ Budiningsih, Pembelajaran Moral, Berpijak Pada Karakteristik Peserta didik dan Budaya, (Jakarta: PT Rineka Cipta 2004), 90 materi/bidang studi; dan (3) karakteristik peserta didik. ${ }^{8}$

Karena uniknya karakteristik mata pelajaran Akidah Akhlak dan pentingnya metode dalam mempengaruhi keberhasilan proses pembelajaran mata pelajaran ini, penulis tertarik untuk mengadakan penelitian tentang metode experiental learning dalam pembelajaran Akidah Akhlak di SMA An-Nuriyyah Bumiayu

Metode experiental learning dikembangkan oleh David Kolb sekitar awal 1980-an. Metode ini merupakan aplikasi dari teori belajar humanistik. Menurut teori humanistik, agar belajar bermakna bagi peserta didik, diperlukan keterlibatan penuh dari peserta didik sendiri. Pada praktiknya, teori humanistik ini cenderung mengarahkan peserta didik untuk berfikir induktif, mementingkan pengalaman, serta membutuhkan keterlibatan peserta didik secara aktif dalam proses pembelajaran. ${ }^{9}$

Baharuddin, mendefinisikan metode experiental learning sebagai tindakan untuk mencapai sesuatu berdasarkan pengalaman yang secara terus-menerus mengalami perubahan guna meningkatkan keefektifan dari hasil belajar itu sendiri. ${ }^{10}$

Berdasarkan latarbelakang di atas, maka penelitian ini difokuskan pada:

1. Bagaimanakah perencanaan dan pelaksanaan metode experiental learning dalam pembelajaran Akidah Akhlak di SMA An-Nuriyyah Bumiayu?

2. Bagaimanakah respon peserta didik terhadap mata pelajaran Akidah Akhlak dengan metode experiental learning di SMA An-Nuriyyah Bumiayu?

8Uno, Orientasi Baru dalam Psikologi Pembelajaran, (Jakarta: Bumi Aksara, cetakan ke 2. 2008),17.

${ }^{9}$ M. Muchith Saekhan, Pembelajaran Kontesktual, (Semarang: Rasail, Media Group 2008),92.

${ }^{10}$ Baharuddin, et.al., Teori Belajar dan Pembelajaran, (Yogyakarta: Ar-Ruzz Media2008), 165. 
Tinjauan Teori Model Pembelajaran Experiential Learning

Experiential Learning Theory (ELT), yang kemudian menjadi dasar model experiential learning, dikembangkan oleh David Kolb sekitar awal 1980-an. Model ini menekan pada sebuah model pembelajaran yang holistik dalam proses belajar. Dalam experiential learning, pengalaman mempunyai peran sentral dalam proses belajar. Penekanan inilah yang membedakan (ELT) dari teori-teori belajar lainnya. Istilah "Experiential Learning" disini untuk membedakan anatara teori belajar kognitif yang cenderung menekankan kognisis lebih dari afektif dan teori belajar behavior yang menghilangkan peran pengalaman subyektif dalam proses belajar. ${ }^{11}$

Teori pembelajaran Kolb (Clark, 2010) terdiri atas empat tahap pembelajaran nyata. Pengalaman Konkret (Concrete Experience), Observasi Reflektif (Reflect Observation), Konseptualisasi Abstrak (Abstract Conceptualization), dan Eksperimentasi Aktif (Active Experiment). Keempat tahap berikut, oleh David Kolb (1984) kemudian digambarkan dalam bentuk lingkaran sebagai berikut:

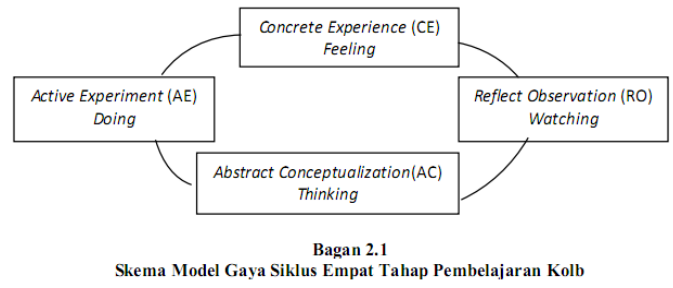

Sesuai empat siklus yang digambarkan oleh Kolb diatas, Experiential Learning dimulai dari sebuah pengalaman konkrit yang menjadi dasar unutuk melakukan tahap refleksi dan observasi terhadap

${ }^{11}$ David Kolb,Experiental Learning(New jersey: Prentice Hall Inc. 1984), 25 pengalaman tersebut. Dalam proses observasi dan refleksi ini siswa berusaha memahami apa yang terjadi atau apa yang dialaminya. Hasil refleksi dalam konsep-konsep abstrak, selanjutnya diuji pada situasi baru. Keempat siklus ini membentuk empat gaya belajar, Knisley menjelaskan sebagai berikut:

1. Konkrit-Reflekrif, merupakan kombinasi dari tahap CE dan RO. Pada gaya ini pembelajaran membangun pemahaman dari pengalaman sebelumnya sehingga pada tahap ini siswa lebih banyak mengumpulkan informasi.

2. Konkrit-Aktif, merupakan kombinasi dari CE dan AE. Pada gaya ini pembelajar belajar dengan trial and eror.

3. Abstrak-Reflektif, merupakan kombinasi dari AC dan RO. Pada gaya ini pembelajar belajar dari deskripsi yang rinci.

4. Abstrak-Aktif, merupakan kombinasi dari AC dan RO. Pada gaya ini pembelajar aktif mengaplikasikan ide-ide abstraknya dan mengembangkan strategi-strategi individulnya. ${ }^{12}$

\section{Metode Penelitian}

\section{Pendekatan Penelitian}

Penelitian ini menggunakan metode penelitian kualitatif yang bersifat deskriptif. Menurut Sugiyono metode penelitian kualitatif adalah metode yang digunakan untuk meneliti pada kondisi objek yang alamiah dimana peneliti sebagai instrument kunci. ${ }^{13}$

12 David Kolb,Experiental Learning...., 35

${ }^{13}$ Sugiyono, Metode Penelitian Kuantitatif Kualitatif dan $R$ \& $D$, (Bandung: Alfabeta, 2007),15. 
Penelitian ini menggunakan pendekatan kualitatif yang bersifat deskriptif karena; pertama, tujuan penelitian ini akan menggambarkan realitas yang kompleks dengan menetapkan penelitian berdasarkan keseluruhan situasi di dalam lingkungan sekolah, ruang kelas, termasuk di dalamnya guru, murid, serta aktifitas pembelajaran. Kedua, penelitian ini dilakukan dalam situasi alamiah dan cara alamiah dimana peneliti termasuk instrument kunci dan tidak membuat perlakuan khusus dalam penelitian. Ketiga, data yang terkumpul akan banyak berbentuk kata-kata, gambar, tulisan, sehingga tidak menekankan pada angka.

\section{Metode Pengumpulan Data}

Untuk memperoleh data yang dibutuhkan, peneliti akan menggunakan metode pengumpulan data yang meliputi:

a. Metode Observasi Partisipatif

Sugiyono mengatakan bahwa dalam observasi partisipatif, peneliti mengamati apa yang dikerjakan orang, mendengarkan apa yang mereka ucapkan, dan berpartisipasi dalam aktivitas mereka. ${ }^{14}$

Pada kegiatan observasi partisipatif ini peneliti akan berperan sebagai guru Bahasa Arab SMA An-Nuriyah yang di luar kelas akan berinteraksi langsung dengan semua komponen pembelajaran yang ada di SMA An-Nuriyyah Bumiayu. Di antaranya adalah

${ }^{14}$ Sugiyono, Metode Penelitian Kuantitatif Kualitatif dan R \& D, (Bandung: Alfabeta, 2007). 311 kepala sekolah, wakil kepala sekolah bidang kurikulum, wakil kepala sekolah bidang kesiswaan, guru bimbingan dan konseling (BK), para wali kelas, para guru mata pelajaran, dan khususnya guru mata pelajaran akidah akhlak. Sedangkan di dalam pembelajaran akidah akhlak, peneliti akan berinteraksi secara tidak langsung dengan peserta didik dengan cara mengikuti dan mengamati proses pembelajaran menggunakan metode experiental learning pada mata pelajaran akidah akhlak.

Selama interaksi tersebut, penulis akan mengamati secara langsung segala sesuatu yang ada di SMA An-Nuriyyah khususnya pelaksanaan metode experiental learning dalam pembelajaran Akidah Akhlak dan perilaku peserta didik dalam pembelajaran ini.

b. Wawancara Terstruktur dan Semiterstruktur.

Wawancara ini akan penulis mulai dari sumber data pertama yaitu, kepala sekolah, wakil kepala sekolah bidang kurikulum, wakil kepala sekolah bidang kesiswaan, mengenai hal-hal yang terkait dengan profil sekolah, program kerja sekolah yang berkaitan dengan pembinaan akhlak, dan data tentang keadaan peserta didik secara menyeluruh.

Selanjutnya peneliti akan mewawancarai guru bimbingan dan konseling (BK) terkait dengan data perilaku dan kasus peserta didik serta penanganannya, guru mata pelajaran Akidah Akhlak yang terkait dengan penerapan metode experiental learning, peserta didik kelas $\mathrm{X}$ yang terkait dengan minat dan perasaan mereka terhadap mata pelajaran Akidah Akhlak dengan 
situasi pembelajaran menggunakan metode experiental learning.

c. Metode Dokumentasi

Data dari hasil observasi dan wawancara dalam penelitian ini akan penulis lengkapi dengan penelitian terhadap data fisik berupa dokumen yang terkait dengan fokus penelitian, seperti buku Kurikulum Tingkat Satuan Pendidikan SMA An-Nuriyyah, buku program kerja bidang kesiswaan dan bimbingan dan konseling, daftar keadaan peserta didik, administrasi dan program pembelajaran guru mata pelajaran akidah akhlak, jurnal kegiatan harian guru akidah akhlak, buku perkembangan peserta didik dan buku kegiatan peserta didik.

\section{d. Analisis Data}

Data yang telah diperoleh melalui observasi partisipatif, wawancara terstruktur, indepth interview, dan dokumentasi dalam penelitian ini akandianalisis menggunakan model Miles dan Hubermen. Aktivitas dalam analisis data model Miles dan Hubermen meliputi data reduction (reduksi data), data display (penyajian data), conclution drawing/verification. ${ }^{15}$

Langkah-langkah analisis data dalam penelitian ini meliputi:

1) Reduksi Data.

Reduksi tersebut terkait dengan data-data hasil observasi partisipatif, wawancara terstruktur, indepth interview, dan dokumentasi yang berhubungan dengan metode experiental learning dalam pembelajaran Akidah Akhlak di SMA An-Nuriyyah Bumiayu. Peneliti

${ }^{15}$ Sugiyono, Metode Penelitian Kuantitatif Kualitatif dan $R \&$ D, (Bandung: Alfabeta, 2007), 337. akan merangkum dan memilih data yang sesuai dengan permasalahan, dan yang tidak sesuai dengan permasalahan disimpan terpisah agar tidak terjadi kekeliruan dalam penyajian data.

2) Penyajian Data

Setelah melakukan reduksi data, selanjutnya peneliti menyajikan data melalui uraian singkat yang bersifat naratif sehingga memudahkan untuk memahami permasalahan dan memudahkan rencana kerja selanjutnya.

3) Penarikan Kesimpulan dan Verifikasi

Kegiatan dalam langkah ketiga ini adalah menarik kesimpulan dan verifikasi terhadap hasil penelitian. Dari kesimpulan dan verifikasi ini diharapkan akan dapat diketahui bagaimana pelaksanaan metodeexperiental learning dalam pembelajaran akidah akhlak, dan bagaimana respon peserta didik terhadap pembelajaran Akidah Akhlak dengan metode experiental learning di SMA An-Nuriyyah Bumiayu.

\section{Hasil dan Pembahasan}

SMA An-Nuriyah menerapkan metode experiental learning sejak tahun ajaran 2016/2017. Adapun dalam menerapkan metode tersebut, guru mata pelajaran berpijak pada dua hal: Pertama, pembelajaran Akidah Akhlak adalah pembelajaran tentang fitrah dan jiwa manusia. Kedua, tujuan pembelajaran Akidah Akhlak lebih dititikberatkan pada aspek kesadaran dan perubahan tingkah laku.

Berdasarkan hasil wawancara peneliti dengan Izzuddin Amaith, guru Aqidah Akhlak SMA An-Nuriyah, bahwa dalam menyampaikan materi pembelajaran dan proses bimbingan 
peserta didik, guru mata pelajaran Akidah Akhlak menekankan pada pemahaman peserta didik terhadap materi-materi yang disampaikan dengan argumen yang kuat dan selanjutnya mampu diterapkan dalam kehidupan sehari-hari. Artinya, pemahaman peseta didik tentang nilai akidah dan akhlak didasarkan pada keyakinan dan alasan yang kuat, sehingga benar-benar dapat menjadi fondasi dalam perilaku kehidupan sehari-hari.

Data tentang pelaksanaan pembelajaran Akidah Akhlak dengan metode experiental learning yang diperoleh di lapangan dapat digambarkan sebagai berikut:

1. Kegiatan pendahuluan

Kegiatan pendahuluan yang dilakukan di SMA AnNuriyyah Bumiayu dapat peneliti paparkan sebagai berikut:

a. Memberikan appersepsi dan motivasi.

Setelah mengecek kehadiran peserta didik, guru memberikan appersepsi dan motivasi. Pada appersepsi ini guru Akidah Akhlak mengingatkan kembali tentang pentingnya pembelajaran Akidah Akhlak, utamanya tentang rukun iman yang akan menjadi fondasi atas semua perbuatan. Guru juga menjelaskan salah satu upaya untuk menjaga iman yang telah dianugerahkan Allah adalah dengan ilmu. Ilmu keimanan terdapat dalam mata pelajaran Akidah Akhlak yang akan dipelajari bersama. Karena itu, guru mengajak peserta didik untuk memperhatikan dan mengikuti pembelajaran dengan sungguh-sungguh.

Appersepsi merupakan langkah menghubungkan materi pelajaran yang lalu dengan materi pelajaran yang akan disampaikan. Appersepsi dan motivasi ini penting karena dalam pembelajaran kesiapan mental diperlukan agar peserta didik mampu dan dapat menerima materi pembelajaran. Menurut Sanjaya dan Djaali, juga menyebutkan bahwa motivasi adalah proses memantapkan perilaku ke arah suatu tujuan. ${ }^{16}$

b. Mengadakan pre test Pada pre test ini, pertama guru Akidah Akhlak meminta beberapa peserta didik yaitu, Ikha Tuslikha, M. Thoriqin, Muhammad Syamsul dan Wahyudin untuk membaca kalimat syahadat dan mengartikannya. Dari keempat peserta didik tidak ada yang dapat mengartikan dengan lengkap dan jelas. Kemudian seorang peserta didik yang bernama Syarifuddin mengangkat tangan dan mampu membaca dan mengartikan syahadat dengan baik dan benar.

Kedua, guru menanyakan sejak kapan mereka mempercayai Allah dengan kesadaran dan meminta mereka menjelaskan alasan/

\footnotetext{
16Wina,Sanjaya, 2008, Strategi Pembelajaran Berorientasi Standar Proses Pendidikan (cet. ke empat), Jakarta: Kencana Prenada Media Group dan
} 
bagaimana mereka percaya akan adanya Allah. Hampir satu kelas serentak menjawab bahwa mereka percaya kepada Allah sejak kecil karena adanya ciptaan Allah berupa langit dan bumi.

Ketiga, Guru bertanya apakah kamu benar-benar mengenal Allah? dan mengapa manusia tidak bisa melihat-Nya? Semua peserta didik terdiam. Ketika pelajaran selesai, peneliti menanyakan kenapa para peserta didik diam dan tidak menjawab pertanyaan yang ke tiga, mereka menjawab takut salah dan takut berdosa.

Mulyasa, menjelaskan bahwa pre test memiliki banyak fungsi dalam pembelajaran, di antaranya

1) untuk menyiapkan peserta didik dalam proses belajar,

2) untuk mengetahui tingkat kemajuan peserta didik sehubungan dengan proses pembelajaran yang dilakukan.

3) untuk mengetahui kemampuan awal yang telah dimiliki peserta didik mengenai bahan pelajaran yang akan dijadikan topik dalam proses pembelajaran;

4) untuk mengetahui dari mana seharusnya proses pembelajaran dimulai, tujuan-tujuan mana yang telah dikuasai oleh peserta didik, dan tujuan-tujuan

$$
\begin{aligned}
& \text { mana yang perlu } \\
& \text { mendapatkan } \\
& \text { penekanan serta } \\
& \text { perhatian khusus. }{ }^{17}
\end{aligned}
$$

c. Membagi kelompok

$$
\text { Saat pembagian }
$$

kelompok suasana langsung berubah. Situasi menjadi semarak dan ramai ketika para peserta didik menggeser tempat duduk, tidak terlihat ada peserta didik yang berdiam diri karena semua aktif melakukan kegiatan menggeser tempat duduk, peserta didik kemudian menempati tempat duduk sesuai dengan kelompoknya masing-masing.

Adapun pembagian kelompok yang dilakukan oleh guru Akidah Akhlak SMA An-Nuriyyah Bumiayu tersebut sesuai dengan tempat duduk peserta didik yang berdekatan.

1) Kelompok I, Winda Astuti, Syahre Saomi, Lia Lafifatul Ghoesti, Wahyudin, Tri Yuni Mulyani, Umi Salipah.

2) Kelompok II, Ahmad Cigi Dianto, Syarifuddin, Muhammad Rudi Hartono, Ali Maskhud, Tuti Zaenab, dan Suci Pujiati.

3) Kelompok III, Dewi Novitasari, Khoeriyah, Nurkhayatun Nikmah, Septiawati, Muji 
Lutfiyadi,

Windi

Wijayanti.

4) Kelompok IV, Nurhaeni, Nurlaeli, Ratu Betti Setiawati, Tuty Zaenab, Sri Andriasih, Nur Rokhim.

5) Kelompok V, Samsul Arifin, Ibrohim, Siti Aliatun Hasanah, Siti Khodijah, Siti Nurlela, Ikha Tuslikah.

Pembagian kelompok seperti ini dimaksudkan untuk mempermudah dan mempercepat proses pengelompokan dan penataan bangku. Selain itu, guru Akidah Akhlak secara pribadi beranggapan bahwa kedekatan tempat duduk merupakan kedekatan emosional. Sehingga dengan kedekatan emosional itu diharapkan peserta didik lebih mudah dan lebih nyaman dalam bekerja sama.

Menurut guru Akidah Akhlak, Drs. Izzuddin Amaith, M.Pd, pembagian kelompok ini tidak permanen, maksudnya pada waktu menyampaikan materi lain maka beliau akan membentuk kelompok baru. Hal ini dilakukan untuk membiasakan peserta didik beradaptasi dengan peserta didik lainnya. Fungsi lain dari pembentukan kelompok baru tersebut juga dapat merangsang peserta didik agar lebih termotivasi dalam kerja kelompok dalam situasi yang baru.

Pembagian kelompok yang dilakukan oleh guru Akidah Akhlak SMA An-
Nuriyyah Bumiayu ini kurang menguntungkan, karena homogenitas taraf kemampuan peserta didik dapat terjadi dalam urutan tempat duduk maupun urutan absensi peserta didik. Askew dan William dalam Muijs dan Reynolds, ${ }^{18}$ menyebutkan bila muridmurid dengan kemampuan yang sama dijadikan satu kelompok (homogen), maka mereka yang memilki kemampuan tinggi menganggap tidak perlu saling membantu, sementara murid-murid yang berkemampuan rendah akan kurang mampu untuk melakukan tugas yang diberikan oleh guru.

d. Menjelaskan standar kompetensi, kompetensi dasar, dan indikator ketercapaian yang hendak dicapai dengan rincian sebagai berikut:

1) menjelaskan makna Iman kepada Allah;

2) mengemukakan argumen tentang tidak benarnya orang yang tidak beriman

3) menguraikan maknaLailahaillallah;

4) menganalisis hikmah iman kepada Allah Menurut Sanjaya, tujuan yang ingin dicapai mesti dipahami oleh setiap peserta didik, karena tujuan akan mengarahkan segala aktivitas pembelajaran dan 
2. Kegiatan Inti

dapat menjadi kontrol dalam pelaksanaan pembelajaran. ${ }^{19}$

Pada permulaan kegiatan inti, guru memberi tugas kepada peserta didik untuk memperhatikan dan mencatat segala hal yang dilihat dan dialaminya. Kemudian guru memperlihatkan kepada peserta didik dalam kelompok, 5 sekor capung yang telah diawetkan dan 5 capung yang masih hidup. Peserta didik mengamati dan sebagian lagi memegang dan memainkannya. Guru meminta peserta didik menerbangkan keduanya. Akhirnya peserta didik tertawa.

$\begin{array}{ccc}\text { Belum } & \text { selesai } & \text { tawa } \\ \text { peserta } & \text { didik, } & \text { guru }\end{array}$
memperlihatkan gambar dari audio-visual tragedi tsunami di Aceh, serta memperlihatkan manusia yang hidup dan manusia yang telah mati. Peserta didik tampak mengamati dan sebagian mengucapkan subhanallah.

Setelah mematikan audiovisual, guru mengajukan pertanyaan yang harus direnungkan dan didiskusikan oleh setiap kelompok:

a. Apakah capung dan manusia yang hidup sama bentuknya dengan capung dan manusia yang mati?

b. Apakah kalian memberinya nama yang sama? Mengapa?

c. Apakah perbedaan yang menonjol antara keduanya?

${ }^{19}$ Wina,Sanjaya, Strategi Pembelajaran Berorientasi StAndar Proses Pendidikan (cet. ke empat), (Jakarta: Kencana Prenada Media Group, 2008), 158 d. Apakah dirimu juga terdiri dari roh dan jasad?

e. Tahukah kamu bagaimana proses jasadmu dibuat?

f. Dan tahukah kamu bagaimana proses ruhmu diciptakan?

g. Apakah kamu bisa melihat dan mendefinisikan seperti apa ruhmu?

h. Apakah seseorang dinilai atau didefinisikan dengan wujud fisiknya atau sifatnya?

i. Carilah ayat al-quran yang menjelaskan tentang ruh! (tugas)

j. Jika kamu yakin bahwa ruhmu yang tidak dapat kamu lihat itu ada, apa pendapatmu dengan yang menciptakan ruh?

Peserta didik diberikan waktu 30 menit untuk merenungkan, mendiskusikan dan menyimpulkan apa yang dilihat dengan kelompoknya. Setelah itu peserta didik diminta oleh guru untuk mempresentasikan hasil renungan dan diskusi kelompoknya.

3. Kegiatan Penutup

Pada kegiatan penutup, guru tampak memberi penjelasan tambahan dan meluruskan pendapat peserta didik tentang keimanan kepada Allah. Kemudian guru memberi kesempatan bertanya. Ada tujuh peserta didik mengangkat tangan untuk bertanya, namun guru hanya mengizinkan dua penanya dan meminta yang lain menulis pertanyaannya di dalam kertas dan guru berjanji akan membahas pertanyaan tersebut apabila ada kesempatan. 
$\begin{array}{ccc}\text { Setelah } & \text { selesai, } & \text { guru } \\ \text { mengajak } & \text { peserta } & \text { didik }\end{array}$ membaca istighfar bersamasama dengan penuh kesadaran dan kesungguhan karena sebagai manusia yang diberi kesempurnaan di antara makhluk yang lain, manusia justru sering lupa akan asalusulnya dan lupa akan penciptanya.

Pada akhir pembelajaran, peserta didik diberi tugas individu membuat rangkuman tentang makna iman kepada Allah dan alasan mengapa manusia harus beriman kepada Allah serta mencari ayat alQur'an yang menjelaskan tentang ruh dan perintah beriman kepada Allah.

Sebelum mengucapkan hamdalah dan salam, guru memberi penghargaan kepada kelompok peserta didik yang kinerjanya baik yaitu kelompok IV dengan meminta tepuk tangan panjang kepada peserta didik satu kelas.

2. Respon Peserta Pada Mata Pelajaran Aqidah Akhlak dengan Metode Experiental Learning

a. Respon Peserta Didik dalam Kegiatan Pembelajaran

Respon yang ditunjukkan peserta didik pada pembelajaran akidah akhlak dengan metode experiental learning di SMA AnNuriyyah Bumiayu dapat digambarkan sebagai berikut:

Berdasarkan pengamatan yang dilakukan oleh peneliti, selama proses pembelajaran Akidah Akhlak berlangsung, mayoritas peserta didik di kelas antusias dan aktif dalam mengikuti proses pembelajaran. Pada kegiatan pendahuluan, dengan apersepsi yang diberikan guru mata pelajaran akidah akhlak, sebagian besar peserta didik tampak berusaha mencari jawaban, yang ditampakkan melalui sikap diam, dan kemudian saling berbisik dan berdiskusi dengan temannya

Respons peserta didik semakin tampak ketika dalam kegiatan inti, guru memberi mereka pengalaman sederhana yang sebenarnya biasa mereka lihat dalam kehidupan seharihari. Pada kelas $\mathrm{X}$, siswa pada setiap kelompok tampak berebut memperhatikan dan memegang capung. Saat pemutaran VCD tentang manusia, mereka juga tampak serius mengikuti dan memperhatikan.

Puncak respon siswa yang paling menonjol adalah pada tahap refleksi dan konseptualisasi. Pada tahap ini peserta didik terlihat menikmati proses berpikir dengan merenung dan berdiskusi dengan teman satu kelompoknya. Sesekali peserta didik juga tampak membolakbalikkan buku pelajaran. Ketika penulis menanyakan kepada peserta didik perihal tersebut setelah selesai pelajaran, mereka menjawab bahwa apa yang mereka lakukan adalah untuk menyesuaikan konsep yang didapat dari pengalaman dengan teori yang ada di dalam buku.

Saat sebagian besar peserta didik dengan serius merenung dan berdiskusi, seorang siswa bernama Suprapto berbisik dan tertawa-tawa dengan teman satu bangkunya yang bernama Imaduddin. Guru menegur dan 
bertanya apakah peserta didik yang bernama Suprapto merasa ada masalah? Peserta didik tersebut mengatakan bahwa dia sedikit bingung. Guru hanya tersenyum dan memintanya untuk berdiskusi dengan kelompoknya.

Pada saat kegiatan penutup, guru memberikan keterangan tambahan untuk meluruskan pemahaman peserta didik tentang materi pelajaran, serta memberikan waktu untuk bertanya. Beberapa peserta didik tampak mengangkat tangan untuk bertanya, namun guru hanya menjawab dua pertanyaan dan meminta peserta didik yang lain menyimpan pertanyaannya untuk waktu dan kesempatan yang lain.

Sunarto (1995) menjelaskan bahwa usia remaja masih dalam proses penyempur-naan penalaran, maka guru harus waspada terhadap bagaimana para peserta didik menginterpretasi ide-ide mereka dalam kelas, dengan memberikan kesempatan untuk mengadakan diskusi dan tanya jawab secara baik. Apabila guru dihadapkan pada perbedaanperbedaan interpretasi, hendaknya menjelaskan konsep-konsep tersebut dengan sabar, simpatik, dan dengan hati terbuka.

Beberapa fenomena yang muncul di dalam kelas tersebut, memberikan indikasi bahwa peserta didik sangat tertarik pada belajar berfikir sehingga respon peserta didik pada pembelajaran akidah akhlak tampak positif seperti antusias, serius, dan merasa asyik.
Keadaan seperti ini dengan sendirinya membangkitkan minat dan motivasi peserta didik untuk belajar. Ketika peneliti melakukan observasi melalui wawancara yang lebih mendalam setelah pembelajaran selesai kepada peserta didik pada kelas $\mathrm{X}$, menunjukkan bahwa peserta didik menyatakan serius mengikuti pelajaran, karena dari appersepsi yang digunakan oleh guru mereka sudah merasa penasaran dengan jawabanjawabannya.

Begitu juga pada wawancara di kelas XI IPA, dari 34 peserta didik hanya 2 orang peserta didik yang tidak menyukai permainan dan 1 orang justru merasa kebingungan. Di antara peserta didik yang menyatakan tidak menyukai metode ini adalah Setiara Fitri Fadilah dan Muthoharoh. Menurut mereka, mereka lebih menyukai metode ceramah karena tidak suka suasana gaduh dan diskusi. Mereka lebih suka mendengar, membaca dan menyimpulkan penjelasan guru. Seorang lagi bernama Suprapto, ia merasa senang dengan metode ini tetapi dia merasa kebingungan ketika harus merenung, menyimpulkan dan berdiskusi. Dari 34 peserta didik, 31 menyatakan senang dan bersemangat sehingga menurut mereka waktu pembelajaran akidah akhlak terasa relatif singkat.

Selain dari pengamatan dalam proses pembelajaran di dalam kelas, peneliti juga mengamati respon peserta didik dalam pembelajaran dengan melihat dokumen absensi 
peserta didik. Berdasarkan dokumentasi absensi, tingkat kehadiran peserta didik pada pembelajaran akidah akhlak relatif baik. Selama satu semester, tingkat kehadiran peserta didik mencapai lebih dari $90 \%$.

Secara umum respon peserta didik dalam mengikuti pembelajaran akidah akhlak dengan metode experiental learning di SMA An-Nuriyyah Bumiayu ini dapat diklasifikasikan menjadi:

1) Peserta didik yang sejak awal pembelajaran cenderung antusias dan aktif mengikuti pembelajaran sampai berakhir pembelajaran. Indikatornya terlihat tampak antusias mengikuti tahapan pembelajaran, serius melakukan refleksi, mengambil kesimpulan dan mendiskusikan materi yang diberikan dalam kelompok dengan baik. Serta aktif mengajukan pertanyaanpertanyaan yang berkaitan dengan materi pelajaran ketika guru memberi kesempatan bertanya.

2) Peserta didik yang kadangkadang tampak memperhatikan dan mengikuti pembelajaran, tetapi sering pula berbicara sendiri dengan teman-teman. Kelompok ini akan kembali mengikuti pembelajaran dengan baik manakala ditegur dan disapa oleh guru.

Dua klasifikasi tersebut menunjukkan bahwa semua peserta didik aktif mengikuti proses pembelajaran dari awal sampai akhir, sekalipun dengan tingkatan yang berbeda. Kenyataan tersebut menunjukkan bahwa peserta didik yang berada di kelas memiliki responyang tinggi berupa perhatian terhadap pembelajaran Akidah Akhlak dengan metode experiental learning.

Mengenai ciri-ciri kelas yang tidak menaruh respon atau yang hanya sedikit perhatiannya terhadap pembelajaran dijelaskan oleh Suryobroto dengan tanda-tanda sebagai berikut:

1) Tata tertib tidak teratur; anak-anak ramai, bercakapcakapsendiri, memperhatikan hal-hal selain pelajaran.

2) Apabila guru bertanya untuk mengulangi, jawaban tidak pernah memuaskan

3) Apabila guru memberi kesempatan untuk bertanya tidak dipergunakan kesempatan ini

4) Apabila guru meninggalkan kelas atau karena pelajaran selesai, murid-murid kelihatan gembira. ${ }^{20}$

Sebaliknya apabila guru mampu membangkitkan perhatian yang penuh dari anakanak, maka bisa diharapkan bahwa:

1) Peserta didik menyongsong pelajaran sehingga bahan bisa diterima dengan baik

2) Tugas dua jiwa yang lain seperti pengamatan yang teliti, berpikir kritis, dan daya assosiasi anak mendapat giliran semestinya.

3) Kepada hal-hal yang kurang digemari terpaksa

${ }^{20}$ Suryobroto, Proses Belajar Mengajar di Sekolah, (Jakarta: PT Rineka Cipta 2002), 170 
diperhatikan, ini adalah suatu latihan kemauan.

Menurut Suryobroto, perhatian peserta didik ada dua macam yaitu, perhatian yang disengaja dan perhatian yang tidak disengaja (spontan). ${ }^{21}$ Keduanya amat penting artinya dalam proses pembelajaran. Oleh sebab itu, guru harus berusaha membangkitkan perhatian tersebut. Hal ini sejalan dengan kenyataan guru Akidah Akhlak dalam membangkitkan perhatian peserta didik melalui cara-cara sebagai berikut:

1) Mempergunakan apersepsi yang telah ada

2) Mempergunakan alat bantu yang menarik

3) Merangsan keaktifan dan minat anak-anak sendiri

4) Memberikan selinganselingan

5) Gaya pembicaraan yang sugesti

6) Menghilangkan hal-hal yang mengganggu perhatian.

7) Menginsafkan peserta didik akan kewajibannya

8) Menginsafkan peserta didik akan faedah mempelajari mata pelajaran tertentu

9) Menimbulkan persainganpersaingan sehat pada peserta didik

10) Tindakan-tindakan penghargaan dari guru

11) Pemberian hukuman bagi yang tidak memenuhi kewajiban. ${ }^{22}$

a. Respons Peserta Didik di Luar Kegiatan Pembelajaran
${ }^{21}$ Ibid
22 Ibid, 171-172
Respons peserta didik yang ditampakkan melalui perhatian yang baik di dalam proses pembelajaran, juga ditampakkan di luar kegiatan pembelajaran. Menurut guru Akidah Akhlak, para peserta didik lebih memilih mengkonsultasikan masalahmasalah pribadi mereka kepada guru mata pelajaran akidah akhlak dari pada berkonsultasi dengan guru Bimbingan dan Konseling (BK). Hal ini dibenarkan oleh Andi Wibisono, guru BK SMA AnNuriyyah, bahwa setiap kali ada masalah peserta didik selalu meminta guru Akidah Akhlak untuk menjadi fasilitator di antara mereka.

Pada saat jam istirahat, ada lima peserta didik yang mendatangi guru Akidah Akhlak, di antaranya adalah Noviyatun Khikmah yang menanyakan mengapa Allah memilih Nabi orang Islam dari bangsa Arab? Kemudian A. Muzakki juga menanyakan apakah sesungguhnya sunnah? apakah semua yang dilakukan Nabi adalah sunnah? dan bagaimana hukumnya bagi orang yang mengikuti ajaran Nabi sebelum Muhammad padahal ia hidup setelah diutusnya Muhammad? Guru Akidah Akhlak menjawab pertanyaan Noviyatun Khikmah dan dua pertanyaan A. Muzakki, sedangkan untuk pertanyaan A. Muzakki yang terakhir, guru akidah akhlak berjanji akan menjelaskannya di dalam kelas pada pertemuan yang akan datang.

Kebiasaan peserta didik mendatangi guru Akidah Akhlak 
pada saat istirahat, dimanfaatkan oleh guru Akidah Akhlak untuk selalu berada di dalam mushalla sekolah saat istirahat. Hal tersebut dilakukan dengan harapan peserta didik yang memiliki masalah akan mendatangi mushalla dan lebih dekat dengan suasana keagamaan. Guru Akidah Akhlak juga membuat jadwal shalat dhuha dan shalat dhuhur berjamaah berdasarkan kelas.

Menurut peserta didik, kebiasaan guru Akidah Akhlak tersebut, memberi dampak positif bagi diri mereka. Dampak itu berupa ketidak canggungan mereka melaksanakan shalat dhuha disekolah pada saat istirahat pertama, serta perasaan nyaman berada di dalam masjid.

Selain kunjungan yang sempat terlihat oleh penulis, guru Akidah Akhlak juga mencatat beberapa kunjungan peserta didik di saat jam istirahat atau ke rumah beliau untuk mengkonsultasikan masalah agama yang mereka hadapi. Salah satu contoh pada akhir semester satu tanggal 12 September 2018, guru Akidah Akhlak mendapat kunjungan dari seorang peserta didik bernama Ali Imron Hamzah (kelas X-1) untuk menanyakan tentang keraguannya terhadap Tuhan. Ia bertanya apa Tuhan itu dan kenapa harus disembah? Lalu, pada tanggal 4 April 2009 peserta didik bernama Farah Abdah kelas XII IPA-2 bertanya tentang apa yang harus kita lakukan terhadap orang yang kita curigai sebagai pencuri?
Respons yang diberikan peserta didik terhadap mata pelajaran Akidah Akhlak berdasarkan pengamatan penulis, tidak semata-mata karena guru mata pelajaran Akidah Akhlak menerapkan metode experiental learningdi dalam pembelajaran di dalam kelas saja. Akan tetapi juga karena guru mata pelajaran Akidah Akhlak menerapkan metode experiental learning tersebut di luar kegiatan pembelajaran, seperti mengajak peserta didik untuk shalat di mushalla sekolah setiap kali ada kesempatan.

Temuan di atas sejalan dengan pendapat Djamarah. Dia menegaskan bahwa hubungan metode mengajar dengan prinsip-prinsip belajar atau asas-asas belajar sangat erat. Relevansi metode mengajar dengan prinsipprinsip belajar akan dapat membangkitkan gairah belajar peserta didik dalam mencapai tujuan pembelajaran. Sebagai pendukung pendapatnya, Djamarah mengemukakan rumusan sebagai berikut:

1) Metode mengajar dan motivasi

Jika bahan pelajaran disajikan secara menarik besar kemungkinan motivasi belajar peserta didik akan semakin meningkat. Motivasi berhubungan erat dengan emosi, minat, dan kebutuhan peserta didik

2) Metode pembelajaran dan aktivitas peserta didik

Apabila dalam kegiatan interaksi edukatif terdapat keterlibatan intelek-emosional peserta didik, biasanya intensitas keaktifan dan motivasi akan meningkat sehingga tujuan pembelajaran dapat dicapai dengan efektif 
3) Metode pembelajaran dan perbedaan individual

Guru harus selalu ingat bahwa peserta didik mempunyai bakat yang berlainan dan mempunyai kecepatan belajar yang bervariasi

4) Metode pembelajaran dan umpan balik

Proses interaksi edukatif memerlukan umpan balik seperti:

a) Umpan balik tentang kemampuan perilaku peserta didik

b) Umpan balik tentang daya serap, misalnya kemampuan menganalisis perolehan melalui refleksi dan diskusi.

5) Metode pembelajaran dan pengalihan

Pembelajaran membentuk peserta didik untuk mengalihkan (transfer) hasil belajarnya ke dalam situasisituasi yang nyata. Metode-metode mengajar tertentu seperti ceramah, dan diskusi kurang menaruh perhatian terhadap pengalihan ini

Metode-metode yang banyak mengandung unsur pengalihan ini adalah metode yang bersifat partisipatif.

6) Metode pembelajaran dan penyusunan Pemahaman yang logis dan psikologis.

Dalam pembelajaran diperlukan pemilihan metode yang tepat. Metode-metode tertentu lebih serasi untuk memberikan informasi mengenai bahan pelajaran atau gagasan-gagasan baru atau untuk menguraikan dan menjelaskan susunan suatu bidang yang luas dan kompleks. Karenanya dalam situasi-situasi tertentu guru tidak dapat meninggalkan metode ceramah atau pemberian kuliah maupun metode pemberian tugas kepada peserta didik, sebab metode ceramah merupakan pendukung bagi materi lain, terutama untuk memberikan penjelasan awal terhadap materi pembelajaran yang akan dipelajari. demikian pula ketika mengambil kesimpulan. ${ }^{23}$

\section{KESIMPULAN}

Kegiatan pembelajaran Akidah Akhlak dengan metode experiental learning yang dilaksanakan di SMA An Nuriyyah Bumiayu dapat memunculkan respons positif dari peserta didik sebagaimana digambarkan dalam deskripsi hasil penelitian di atas, disebabkan karena guru mata pelajaran Akidah Akhlak memperhatikan asas-asas belajar dalam pembelajarannya.

\section{Referensi}

Ancok, Jamaluddin, Out Bound Management Training, Aplikasi Ilmu perilaku Dalam Pengembangan Sumber Daya Manusia, Yogyakarta: UII Press, 2003.

Baharuddin, et.al., Teori Belajar dan Pembelajaran, Yogyakarta: ArRuzz Media, 2008.

Baharuddin, Paradigma Psikologi Islami, Yogyakarta: Pustaka Pelajar, 2004.

Budiningsih, Pembelajaran Moral, Berpijak Pada Karakteristik Peserta didik dan Budaya, Jakarta: PT Rineka Cipta, 2004.

Daulay, Pendidikan Islam Dalam Sistem Pendidikan Nasional Indonesia, (cet. ketiga),

${ }^{23}$ Djamarah, Guru dan Peserta didik Dalam Interaksi Edukatif; Suatu pendekatan teoritis Psikologis, (Jakarta: PT Rineka Cipta 2005), 223 
Jakarta: Kencana Prenada Media Group, 2007

Darajat, Zakiyah, Ilmu Jiwa Agama, Jakarta: Bulan Bintang, 2005.

Djamarah, et.al., Strategi Belajar Mengajar, (edisi ketiga), Jakarta: PT Rineka Cipta, 2006.

- Guru dan Peserta didik Dalam Interaksi Edukatif; Suatu pendekatan teoritis Psikologis, Jakarta: PT Rineka Cipta, 2005.

Fathurrohman, Strategi Belajar Mengajar, Strategi Mewujudkan Pembelajaran Bermakna Melalui Penanaman Konsep Umum dan Konsep Islami, Bandung: PT Refika Aditama, 2007.

Hollingworth dan Lewis, Pembelajaran aktif; meningkatkan keasyikan Kegiatan di Kelas, Terj: Dwi Wulandari, Jakarta: PT Macanan Jaya Cemerlang, 2008.

Ismail, Strategi pembelajaran Agama Islam Berbasis PAIKEM, Semarang: Rasail Media Group, 2008.

Kolb, David, Experiental Learning, New jersey: Prentice Hall Inc.1984.

Kurikulum Tingkat Satuan Pendidikan (KTSP) SMA An-Nuriyyah Bumiayu, 2006

Langgulung, Hassan, Manusia dan Pendidikan: Suatu Analisa Psikologi dan Pendidikan, Jakarta: Pustaka Al-Husna, 1986.

Majid Abdul, Perencanaan Pembelajaran:

Mengembangkan StAndar Kompetensi Guru, Bandung: Rosda Karya Offsett, 2006.

Maksum, Madrasah; Sejarah dan Perkembangannya, Jakarta: PT Logos Wacana Ilmu, 1999.
Muhaimin, Wacana Pengembangan Pendidikan Islam, Surabaya: Pusat Studi Agama, Politik, dan Masyarakat (PSAPM), 2003.

Kawasan dan Wawasan Studi Islam, (cet kesatu) Jakarta: Prenada Media, 2005.

, Nuansa Baru Pendidikan Islam, Mengurai Benang Kusut Pendidikan Islam, Jakarta: PT Raja Grafindo Persada, 2006. dan Sutiah, Paradigma Pendidikan Islam, Bandung: Remaja Rosda Karya, cet. 2, 2002.

dan Mujib, Pemikiran Pendidikan Islam (Kajian filoso.fis dan kerangka dasar operasionalisasinya),

Bandung: PT Trigenda Karya, 1993.

Muchith, M. Saekhan, Pembelajaran Kontesktual, Semarang: Rasail, Media Group, 2008.

Muhadjir, Noeng, Metode Penelitian Kualitatif, Edisi III, Yogyakarta: Rake Sarasin, 1996.

Muijs, Daniel dan Reynold, David, Effective Teaching, Teori dan Aplikasi, Yogyakarta: Pustaka Pelajar, 2008.

Mulyasa, E., Kurikulum Berbasis Kompetensi: Konsep, Karakteristik dan Implementasi, Bandung: PT. Remaja Rosdakarya, 2004

Muslich, Masnur, KTSP Pembelajaran Berbasis Kompetensi dan Kontekstual, cet. 3, Jakarta: Bumi Aksara, 2008.

Sanjaya, Wina, Strategi Pembelajaran Berorientasi StAndar Proses Pendidikan (cet. ke empat), Jakarta: Kencana Prenada Media Group, 2008. 
Soejono dan Abdurrahman, Metode

Penelitian, Suatu Pemikiran dan

Penerapan, Jakarta: PT. Rineka

Cipta, 1999.

Sugiyono, Metode Penelitian Kuantitatif Kualitatif dan $R \& D$, Bandung: Alfabeta, 2007.

Suryobroto, Proses Belajar Mengajar di Sekolah, Jakarta: PT Rineka Cipta, 2002.

Syukur, Fatah, 2005, Prinsip-Prinsip Pembelajaran, Semarang: Rasail

Uno, Hamzah B., Rencana Pembelajaran, (cet. ketiga), Jakarta: PT Bumi Aksara, 2008.

Orientasi Baru dalam Psikologi

Pembelajaran, Jakarta: Bumi Aksara, 2008. 